\title{
NASTĘPSTWA NOWELIZACJI PRAWA UPADŁOŚCIOWEGO I NAPRAWCZEGO WPROWADZONYCH NA PRZESTRZENI LAT 2009-2011
}

\section{WSTEP}

Zasady wspólnego dochodzenia roszczeń wierzycieli od niewypłacalnych dłużników w Polsce reguluje ustawa z 28 lutego 2003 r. - Prawo upadłościowe i naprawcze (dalej p.u.n.), która weszła w życie 1 października 2003 r. Do tego czasu obowiązywały w Polsce rozporządzenia Prezydenta Rzeczypospolitej Polskiej z 24 października 1934 r.: Prawo upadłościowe oraz Prawo o postępowaniu układowym. Od momentu wejścia w życie ustawa była wielokrotnie nowelizowana. Ostatnie, znaczące - zdaniem autorów - nowelizacje miały miejsce 6 marca 2009 r., 22 października 2010 r. oraz 9 czerwca 2011 r. W artykule przeanalizowane zostały ekonomiczne i prawne skutki tych nowelizacji dla upadłego przedsiębiorcy, jego wierzycieli oraz pozostałych interesariuszy postępowania upadłościowego. Zaprezentowany został również możliwy wpływ wprowadzonych zmian na przejrzystość procedur upadłościowych.

Wyniki badań Banku Światowego prowadzonych co roku w krajach całego świata i umieszczanych w raporcie Doing Business wskazują na potrzebę wprowadzenia kolejnych reform p.u.n. Według danych zmieszczonych w najnowszej edycji raportu pod względem oceny procedur upadłościowych Polska zajmuje 37 miejsce na $185^{1}$. Kluczowe charakterystyki postępowań upadłościowych brane pod uwage przy ocenie tych procedur to: czas trwania postępowania, koszty postępowania i stopień odzyskiwanych wierzytelności, natomiast ranking sporządzany jest na podstawie stopy odzyskiwanych wierzytelności. Trzy wymienione charakterystyki są jednocześnie najczęściej opisywanymi w literaturze miernikami efektywności ekonomicznej postępowań upadłościowych ${ }^{2}$. Postępowanie upadłościowe efektywne ekonomicznie jest

${ }^{1}$ World Bank, Doing Business 2013: Smarter Regulations for Small and Medium-Size Enterprises. Washington, DC: World Bank Group, 2013, http://www.doingbusiness.org/ /media/GIAWB/Doing\% 20Business/Documents/Annual-Reports/English/DB13-full-report.pdf, s. 189 (dostęp: 19.11.2012).

${ }^{2}$ Zob. np. O. Couvenberg, A. de Jong, Costs and Recovery Rates it the Dutch Liquidation-Based Bankruptcy System, „European Journal of Law and Economics” 26, 2008, nr 2, s. 105-127; B. Prusak, Metody i mierniki oceny efektywności postępowań i systemów upadtościowych, „Pieniądze i Więź” 2010, nr 1 (46), s. 144-154; K. Thorburn, Bankruptcy Auctions: Costs, Debt Recovery, and Firm Survival, „Journal of Financial Economics” 58, 2000, nr 3, s. 337-368. 
to postępowanie trwające jak najkrócej, maksymalizujące kwoty wypłacone wierzycielom przy jednoczesnym ograniczaniu kosztów z nim związanych. Zgodnie z wynikami badań Banku Swiatowego postępowanie upadłościowe w Polsce trwa średnio 3 lata, pociagga za sobą koszty w wysokości 15\% majątku upadającego przedsiębiorstwa, a w wyniku jego przeprowadzenia wierzyciele odzyskują średnio 54,5\% swoich należności ${ }^{3}$. Opinie teoretyków i praktyków prawa upadłościowego ${ }^{4}$ wskazuja na konieczność wdrażania reform prawa, które będą zmierzały do poprawy efektywności ekonomicznej postępowań oraz uproszczenia istniejących procedur upadłościowych. Zarządzeniem Ministra Sprawiedliwości z 14 maja 2012 r. powołano Zespół do spraw Nowelizacji Prawa Upadłościowego i Naprawczego, którego celem było m.in. opracowanie rekomendacji zmian w p.u.n. ${ }^{5}$ Częste zmiany przepisów prawa nie sprzyjaja jednak utrzymaniu stabilnych warunków prowadzenia działalności gospodarczej. Dlatego przed opracowaniem kolejnej nowelizacji konieczne jest zidentyfikowanie potencjalnych wad ustawy $\mathrm{w}$ jej obecnym brzmieniu, dokonanie analizy skutków dotychczas wprowadzonych zmian oraz zweryfikowanie, czy ich postulowany kierunek jest zbieżny z faktycznie obserwowanym. Ze względu na obszerną i wyczerpująca literaturę dotycząca diagnozy problemów i postulowanych reform p.u.n. ${ }^{6} \mathrm{w}$ niniejszym artykule skupiono się na analizie najważniejszych, zdaniem autorów, zmian w przepisach, które wprowadzono w p.u.n. w ostatnich latach oraz przedstawiono ich skutki ekonomiczne i prawne.

Każda z wymienionych nowelizacji została omówiona w oddzielnej części artykułu, w podsumowaniu podjęto próbę dokonania oceny istotności przeprowadzonych do tej pory reform p.u.n. W artykule celowo pominięte zostały zagadnienia związane ze zmianami w przepisach z zakresu międzynarodowego postępowania upadłościowego, postępowania upadłościowego wobec banków, zakładów ubezpieczeń oraz postępowania naprawczego, jako że stanowia one odrębne i obszerne działy tematyczne, które powinny stać się przedmiotem osobnych rozważań.

\section{EKONOMICZNY CHARAKTER ZMIAN WPROWADZONYCH W P.U.N.}

Za zmiany o charakterze ekonomicznym zostały w niniejszym artykule uznane przede wszystkim zmiany p.u.n. oddziałujące na najczęściej przywoływane w literaturze mierniki efektywności ekonomicznej postępowań

\footnotetext{
${ }^{3}$ World Bank, op. cit., s. 189.

${ }^{4}$ Zob. np. J. Horobiowski, Podstawowe warunki skutecznej reformy prawa sadownictwa upadtościowego $w$ celu dostosowania ich do specyfiki $i$ potrzeb obrotu gospodarczego $w$ Polsce, Konferencja „Ekonomia i prawo upadłości przedsiębiorstw - polska praktyka względem międzynarodowych standardów”, Szkoła Główna Handlowa, Warszawa, 26-27 listopada 2009 r.

${ }^{5}$ Dz. Urz. Min. Sprawiedl. z 1 czerwca 2012 r., poz. 83. Rekomendacje dostępne są na: http://ms.gov.pl/pl/nowelizacja-prawa-upadlosciowego-i-naprawczego/.

${ }^{6}$ Zob. np. J. Horobiowski, op. cit.; A. Czapracka, S. Morawska, Praktyka stosowania prawa upadtościowego a cele regulacji, w: E. Mączyńska (red.), Meandry upadtości przedsiębiorstw. Klęska czy druga szansa?, Szkoła Główna Handlowa w Warszawie, Warszawa 2009, s. 129-142.
} 


\section{Schemat 1}

Wpływ zmian wprowadzonych nowelizacjami p.u.n. na charakterystyki postępowania upadłościowego

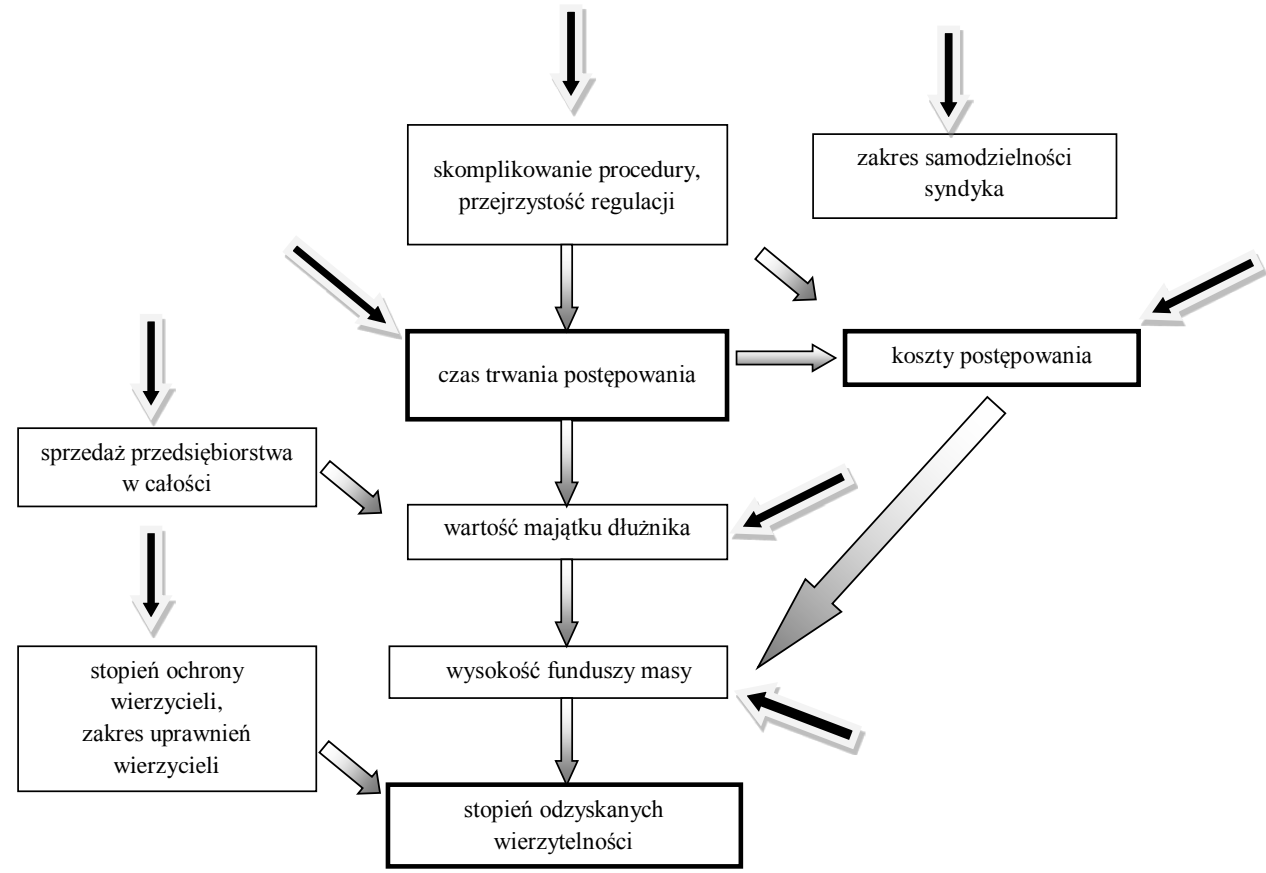

$\longrightarrow$ zmiana pierwotna, oddziałująca na daną charakterystykę bezpośrednio
$\square$ zmiana wtórna (wynikająca z innej zmiany), oddziałująca na daną charakterystykę

Źródło: opracowanie własne.

upadłościowych i w przedmiocie ogłoszenia upadłości, między którymi zachodzą liczne zależności przedstawione na schemacie 1. Dłuższe postępowanie upadłościowe prowadzi z reguły do wzrostu jego kosztów oraz spadku wartości majątku dłużnika, a więc zmniejszenia kwot możliwych do uzyskania z jego sprzedaży. To z kolei skutkuje zmniejszeniem środków pozostających do podziału pomiędzy wierzycieli, czyli przyczynia się do spadku stopy odzyskiwanych wierzytelności.

Do zmian wywołujących skutki ekonomiczne zaliczono również takie zmiany p.u.n., które pośrednio wpływają na efektywność ekonomiczna postępowań upadłościowych. Zaliczyć należy do nich zmiany, które oddziałując na stopień ochrony wierzycieli upadającego przedsiębiorcy i zakres ich uprawnień w postępowaniu upadłościowym, wpływają na szybkość windykacji i stopień odzyskiwanych wierzytelności. Zmiany o charakterze ekonomicznym to również zmiany oddziałujące na zakres samodzielności syndyka, stopień 
skomplikowania procedur, a tym samym na przejrzystość regulacji. Wpływaja one na czas trwania postępowań oraz wysokość kosztów, które się z nimi wiążą.

$\mathrm{Z}$ ekonomicznego punktu widzenia istotną grupą zmian są również zmiany przyczyniające się do zwiększenia szans sprzedaży przedsiębiorstwa jako funkcjonującej całości, czyli „zachowania dotychczasowego przedsiębiorstwa dłużnika"7. Przedsiębiorstwo sprzedane jako całość jest z reguły warte więcej niż sprzedawane w częściach, co w oczywisty sposób wpływa na wysokość funduszy masy upadłości. W sytuacji zaprzestania prowadzenia działalności przez dłużnika i sprzedaży jego przedsiębiorstwa w częściach likwidacji ulegają miejsca pracy, które nie zawsze zostaną odtworzone. Ma to szczególne znaczenie w wypadku dużych przedsiębiorstw oraz przedsiębiorstw będących jedynymi pracodawcami w regionie, w którym funkcjonują. Ich likwidacja przyczynia się do wzrostu bezrobocia, co z kolei wiąże się $\mathrm{z}$ innymi, niekorzystnymi konsekwencjami ekonomiczno-społecznymi.

\section{NOWELIZACJA P.U.N. Z 6 MARCA 2009 R.}

Ustawa z 6 marca 2009 r. o zmianie ustawy - Prawo upadłościowe i naprawcze, ustawy o Bankowym Funduszu Gwarancyjnym oraz ustawy o Krajowym Rejestrze Sądowym ${ }^{8}$ wprowadziła najwięcej zmian spośród trzech nowelizacji wymienionych we wstępie niniejszego artykułu. Poniżej omówione zostały tylko najistotniejsze $\mathrm{z}$ nich, które w swoich skutkach dotyczą przede wszystkim skrócenia postępowania w przedmiocie ogłoszenia upadłości oraz postępowania upadłościowego i ułatwienia likwidacji majątku dłużnika, w tym uproszczenia procedur jego sprzedaży.

Ważną zmianą wprowadzoną nowelizacją p.u.n. w marcu 2009 r. jest zmiana art. 27 ust. 3 p.u.n. polegająca na wyznaczeniu miesięcznego terminu (od dnia przedstawienia akt sprawy) na rozpoznanie przez sad drugiej instancji zażalenia na postanowienie w sprawie ogłoszenia upadłości. Przed nowelizacja termin taki nie był w ogóle określony. Wprowadzenie tej zmiany wiąże się z przyspieszeniem zapadnięcia rozstrzygnięcia, a tym samym skróceniem czasu trwania postępowania. Rozstrzygnięcie może przybrać jedna z dwóch form: utrzymania w mocy postanowienia sądu pierwszej instancji albo przekazania mu sprawy do ponownego rozpatrzenia. Jeśli sąd pierwszej instancji wyda postanowienie o ogłoszeniu upadłości, szybsze rozpoznanie zażalenia przez sąd drugiej instancji i utrzymanie w mocy postanowienia sądu pierwszej instancji zapobiegnie spadkowi wartości majątku dłużnika i doprowadzi do szybszego zawieszenia postępowań egzekucyjnych $\mathrm{z}$ tego majątku, jeśli nie zostały one wcześniej zawieszone postanowieniem sądu. To z kolei zapobiega wyprzedawaniu składników majątku upadającego przedsiębiorcy i zaspokajaniu wierzycieli poza ustalona $\mathrm{w}$ p.u.n. kolejnością. $\mathrm{W}$ wypadku zażalenia na postanowienie, w którym sąd ogłosił upadłość dłużnika, szybsze rozstrzygnięcie

7 S. Gurgul, Prawo upadtościowe i naprawcze. Komentarz, wyd. 7, C. H. Beck, Warszawa 2010, s. 19.

${ }^{8}$ Dz. U. 2009, Nr 53, poz. 434. 
w postaci przekazania sprawy do ponownego rozpoznania sądowi pierwszej instancji może być korzystne dla relacji dłużnika z kontrahentami. Jeśli sąd pierwszej instancji w takiej sytuacji oddali wniosek, który został złożony przez wierzyciela, umożliwi poprawę reputacji dłużnika i jego relacji z kontrahentami. Prawdopodobne jest bowiem, że kontrahenci wiedząc, że w sądzie toczy się postępowanie w przedmiocie ogłoszenia upadłości, będą, w optymistycznym scenariuszu, wykazywać większą ostrożność przy zawieraniu kontraktów z potencjalnym upadłym, a w pesymistycznym - mogą nawet odstąpić od wszelkich kontaktów handlowych z dłużnikiem. Jeśli wniosek o ogłoszenie upadłości złożony był przez dłużnika, który wnosił o upadłość układowa, a sąd ogłosił upadłość likwidacyjną, szybsze przekazanie sprawy do ponownego rozpatrzenia przez sąd pierwszej instancji na skutek wniesienia zażalenia również może pozytywnie wpłynąć na relacje $\mathrm{z}$ wierzycielami, szczególnie tymi, których dotyczy układ.

Wprowadzenie terminu na rozpoznanie zażalenia na postanowienie o ogłoszeniu upadłości jest również istotną zmianą z tego powodu, że czas od momentu wydania postanowienia o ogłoszeniu upadłości do momentu jego uprawomocnienia się jest stanem swoistego zawieszenia wykonywania czynności przewidzianych przepisami prawa upadłościowego. Postanowienie nie uprawomocni się, dopóki w określonym przepisami prawa terminie będą wpływały zażalenia. Syndyk wykonuje wprawdzie w tym czasie czynności, ale w zasadzie powinien powstrzymać się od działań, które prowadza do nieodwracalnych skutków, np. w stanie majątku dłużnika, pomimo że przepisy ustawy nie zabraniaja podejmowania takich działań. Gdy brak środków na pokrycie kosztów postępowania, syndyk może bowiem dokonać sprzedaży składników majątku masy upadłości. Termin miesiąca na rozpatrzenie zażalenia narzucony sądowi w art. 27 p.u.n. jest terminem jedynie instrukcyjnym i sąd może go nie dotrzymać, np. ze względu na duży stopień skomplikowania sprawy. Praktyka pokazuje, że sądy starają się dotrzymywać wyznaczonych im terminów o takim charakterze, ale nie są odosobnione wypadki, gdy zażalenia rozpatrywane sa nawet przez kilka miesięcy.

Istotną zmianą wprowadzoną nowelizacją z marca $2009 \mathrm{r}$. jest także nadanie nowego brzmienia artykułom 36 i 38 p.u.n. Przed nowelizacją w postępowaniu w przedmiocie ogłoszenia upadłości sąd z urzędu przeprowadzał postępowanie zabezpieczające. Obecnie sąd dokonuje z urzędu zabezpieczenia majątku tylko wtedy, gdy wniosek jest składany przez dłużnika. W przeciwnym wypadku zabezpieczenia dokonuje się tylko na wniosek podmiotu, który go składa. Dodatkowo wprowadzono zmianę w sposobie zabezpieczenia majątku dłużnika: sąd może, ale nie musi ustanawiać tymczasowego nadzorcy sądowego. Do czasu wejścia $\mathrm{w}$ życie nowelizacji sąd $\mathrm{z}$ urzędu zabezpieczał majątek przez ustanowienie nadzorcy. Zmiana ta prowadzi przede wszystkim do zmniejszenia kosztów postępowania w przedmiocie ogłoszenia upadłości o kwotę wynagrodzenia tymczasowego nadzorcy sądowego i wszelkie inne koszty związane z jego czynnościami, które zawsze wykonywane są na rachunek upadłego i powoduja zmniejszenie funduszy pozostających do podziału między wierzycieli. Ponadto w tych wydziałach gospodarczych sądów rejonowych, w których przyjęto zasadę, że tymczasowy nadzorca sądowy (powoływany do czasu wejścia w życie 
nowelizacji obligatoryjnie) ma obowiązek sporządzenia opinii o stanie przedsiębiorstwa dłużnika, brak jego powołania może skutkować szybszym wydaniem postanowienia o ogłoszeniu upadłości ze względu na brak konieczności oczekiwania na złożenie takiej opinii. Z drugiej strony obligatoryjne powołanie tymczasowego nadzorcy sądowego sprzyjało ograniczeniu ponoszenia zbędnych kosztów przez dłużnika. Praktyka pokazuje, że dłużnicy we wnioskach o ogłoszenie upadłości przedstawiaja z reguły zniekształcony obraz swojej sytuacji finansowo-ekonomicznej. Jej weryfikacja przez tymczasowego nadzorce sądowego mogła spowodować oddalenie wniosku, co zapobiegało ponoszeniu przez dłużnika kosztów postępowania upadłościowego w sytuacji, gdy miałoby ono zostać w przyszłości umorzone ze względu na brak majątku na pokrycie kosztów postępowania. Nieobligatoryjne zabezpieczenie majątku może mieć także negatywne skutki dla masy upadłości w wypadku złożenia wniosku o ogłoszenie upadłości dłużnika przez jego wierzyciela. Istnieje ryzyko, że dłużnik niezgadzający się $\mathrm{z}$ wnioskiem spróbuje dokonać transakcji niezgodnych z prawem, których skutkiem będzie uszczuplenie jego majątku. Nawet jeśli czynności te zostaną uznane za bezskuteczne $\mathrm{w}$ stosunku do masy upadłości, ich późniejsze odwrócenie może być czasochłonne, co negatywnie wpłynie na koszty postępowania.

Nowelizacja z 6 marca 2009 r. zmieniono także art. 45 ust. 3 p.u.n., który w całości dotyczy uchwał podejmowanych przez wstępne zgromadzenie wierzycieli. Przed tą zmianą na wstępnym zgromadzeniu wierzycieli tylko tymczasowy nadzorca sądowy lub zarządca, jeśli był ustanowiony, mógł sporządzić spis wierzytelności pod nadzorem sędziego. W rzeczywistości w procesie tym musiał uczestniczyć także dłużnik, który dostarczał wskazanym osobom informacje o swoich wierzycielach. Obecnie prawo sporządzenia projektu spisu wierzytelności przyznano wprost także dłużnikowi. Wprowadzenie tego zapisu jest niewątpliwie konsekwencja zmiany przepisu art. 38 p.u.n., w którym zniesiono obowiązek ustanawiania tymczasowego nadzorcy sądowego. Jeżeli nie zostaje on powołany, jedyną stroną postępowania posiadającą pełną wiedzę o zobowiązaniach dłużnika i ich kwotach jest sam dłużnik. Umożliwienie mu sporządzenia projektu spisu wierzytelności jest więc $\mathrm{w}$ pełni uzasadnione. Ponadto nowa treść art. 38 p.u.n. jest bardziej adekwatna do faktycznego przebiegu procesu sporządzania spisu wierzytelności i rzeczywistego zaangażowania uczestników postępowania w jego realizację.

W wyniku nowelizacji p.u.n. w marcu 2009 r. zmieniła się również treść art. 84 definiującego bezskuteczną czynność prawną. Postanowienie umowy, której stroną jest upadły, w nowym brzmieniu przepisu jest bezskuteczne $\mathrm{w}$ stosunku do masy, jeżeli utrudnia lub uniemożliwia osiagnięcie celu postępowania. Wcześniej czynność była bezskuteczna wobec masy tylko wtedy, gdy została dokonana $\mathrm{z}$ naruszeniem ustawy. Zmiana ta ułatwia i przyśpiesza prowadzenie likwidacji majątku masy upadłości, gdyż pozwala na uznanie za bezskuteczne takie postanowienia umów, które - gdyby miały zostać wykonane przez syndyka - uniemożliwiłyby przeprowadzenie postępowania upadłościowego w rozsądnym czasie. Przykładem takich umów są zawarte przez dłużnika wieloletnie umowy najmu lub dzierżawy składników jego majątku. Wydłużenie postępowania upadłościowego tylko z powodu konieczności wykonania postano- 
wień umów, których stroną jest upadły, a zbędnych z punktu widzenia postępowania upadłościowego, z reguły wiąże się ze wzrostem kosztów postępowania. W efekcie fundusze masy upadłości ulegają uszczupleniu, a wierzyciele zostaja zaspokojeni w mniejszym stopniu. Do art. 84 p.u.n. dodano również ust. 2 , zgodnie z którym umowy przeniesienia praw zawarte, aby zabezpieczyć wierzytelności, sa skuteczne $\mathrm{w}$ stosunku do masy tylko wtedy, gdy zostały zawarte $\mathrm{w}$ formie pisemnej z datą pewną. Treść przepisu art. 84 p.u.n. w zmienionym brzmieniu nie pozwala zatem na niesłuszne uprzywilejowanie przez upadłego wybranych wierzycieli po ogłoszeniu upadłości, a tym samym chroni interesy wierzycieli jako ogółu. Zapobiega bowiem uszczupleniu funduszy masy, które miałoby miejsce, gdyby prawa do rzeczy będącej składnikiem majątku upadłego zostały przeniesione $\mathrm{w}$ sposób niezgodny $\mathrm{z}$ prawem, np. poprzez antydatowanie umowy przeniesienia własności rzeczy na zabezpieczenie wierzytelności.

Kolejną istotna zmianę wprowadzono w art. 165 ust. 2, 3, 4 p.u.n., dotyczącym ustalenia ostatecznej wysokości wynagrodzenia syndyka. Do momentu wejścia w życie nowelizacji kwota ostatecznego wynagrodzenia syndyka mogła zostać ustalona dopiero po zatwierdzeniu przez sąd ostatecznego sprawozdania syndyka. Obecnie ostateczną wysokość wynagrodzenia sąd ustala po zatwierdzeniu ostatecznego sprawozdania syndyka z działalności lub przed jego zatwierdzeniem, jeśli może tego dokonać na podstawie zatwierdzonych dotychczas sprawozdań okresowych. Wypłata wynagrodzenia następuje jednak dopiero po zatwierdzeniu ostatecznego sprawozdania. Ułatwia to sporządzenie ostatecznego planu podziału funduszy masy upadłości. Przed nowelizacją syndyk mógł jedynie szacować kwotę, która zostanie mu przyznana. Ustalając kwotę do podziału pomiędzy wierzycieli, był on zobligowany uwzględnić rezerwę na koszty postępowania związane m.in. ze swoim wynagrodzeniem. W wypadku gdy rezerwa okazywała się zbyt wysoka, konieczne było sporządzenie dodatkowego planu podziału kwoty pozostałej w masie upadłości, co generowało koszty związane z publikacją ogłoszeń i obwieszczeń i wydłużało czas prowadzenia postępowania. Pomimo nowelizacji przy sporządzaniu planu podziału nadal istnieje jednak ryzyko, że rezerwa założona przez syndyka okaże się zbyt wysoka, dlatego że po sporządzeniu ostatecznego sprawozdania i planu podziału nadal ponosi on inne koszty, które niełatwo jest precyzyjnie oszacować ex ante, szczególnie, że czas od momentu złożenia ostatecznego planu podziału do momentu uznania postępowania za zakończone może wynosić nawet kilka miesięcy. Natomiast w wypadku gdy wspomniana rezerwa okazuje się zbyt niska, syndyk musi pokryć koszty z własnych środków, co nie jest jednak dodatkowym obciążeniem dla masy upadłości.

Istotna zmiana prowadząca do zwiększenia samodzielności syndyka w postępowaniu upadłościowym jest modyfikacja art. 179 p.u.n., który przed nowelizacją z marca 2009 r. dotyczył zatrudniania innych osób przez syndyka oraz zlecania im wykonania czynności. Jeśli syndyk musiał zatrudnić inne osoby i nie uwzględnił kosztów z tym związanych w preliminarzu wydatków, zobowiązany był każdorazowo uzyskać na takie działanie zgodę sędziego komisarza. Ograniczało to możliwości działania syndyka oraz wydłużało czas trwania postępowania ze względu na konieczność oczekiwania na 
postanowienie w przedmiotowej sprawie. Obecnie art. 179 p.u.n. w całości dotyczy sposobu podejmowania jakichkolwiek działań przez syndyka. Ma on obowiązek podejmowania działań z należytą starannością, tak aby umożliwiać optymalne wykorzystanie majątku dłużnika. Oznacza to, że syndyk powinien dążyć do minimalizowania kosztów postępowania, a tym samym do maksymalizowania kwot przekazanych wierzycielom. Zrezygnowano więc z uzależnienia zatrudnienia osoby trzeciej lub, ogólniej, poniesienia jakiegokolwiek wydatku od zgody sędziego komisarza. Zwiększa to zakres samodzielności syndyka i umożliwia mu szybsze wykonanie czynności koniecznych do sprawnego prowadzenia postępowania upadłościowego. Nie oznacza to jednak dowolności w wydatkowaniu środków zgromadzonych w masie - syndyk zobowiązany jest do optymalizowania poziomu kosztów postępowania.

Korzystne dla dłużnika i nabywcy jego nieruchomości jest uzupełnienie art. 313 ust. 2 p.u.n. o stwierdzenie, że podstawą do wykreślenia hipoteki dla nieruchomości upadłego, sprzedanej w toku postępowania upadłościowego, jest umowa sprzedaży nieruchomości. Przed nowelizacja prawdopodobny nabywca nieruchomości czekał na wykreślenie hipoteki do momentu uprawomocnienia się planu podziału, pomimo że nabywał nieruchomość wolną od hipotek. Jeśli chciał on zaciągnąc kredyt na zakup zbywanej przez dłużnika nieruchomości, bank miał prawo zażądać dodatkowego zabezpieczenia kredytu z powodu wpisanej w księdze wieczystej hipoteki. To z kolei mogło spowodować wycofanie się potencjalnego nabywcy ze złożonej oferty. Sytuacje takie nie są korzystne z punktu widzenia maksymalizacji efektywności postępowania upadłościowego. Czas, jaki upływa do momentu znalezienia kolejnego nabywcy, negatywnie wpływa na wartość nieruchomości, a więc także powoduje obniżenie kwoty przeznaczonej do podziału między wierzycieli dłużnika. Poszukiwanie kolejnego nabywcy wiąże się także $\mathrm{z}$ ponoszeniem dodatkowych kosztów utrzymania i ochrony nieruchomości oraz ogłoszeń o planach jej sprzedaży.

Podobne znaczenie dla efektywności postępowania upadłościowego ma zmiana treści art. 321 ust. 1 p.u.n., który dotyczy zawarcia umowy sprzedaży mienia upadłego. Obecnie czas na zawarcie takiej umowy może wynieść maksymalnie cztery miesiące od momentu zatwierdzenia oferty przez sędziego komisarza, co oznacza, że wydłużono go aż o trzy miesiące. Nabywca ma więcej czasu na szukanie źródeł finansowania zakupu mienia i większe są szanse na to, że faktycznie takie znajdzie. Mienie zbywane w trakcie postępowania upadłościowego zazwyczaj jest mało atrakcyjne lub bardzo specyficzne, co sprawia, że grono podmiotów zainteresowanych jego kupnem jest wąskie, a najczęściej ogranicza się do jednego oferenta. W interesie wszystkich uczestników postępowania upadłościowego jest więc ułatwienie dokonania transakcji zakupu tego mienia. Szczególnie ważne jest to w wypadku, gdy sprzedaż dotyczy przedsiębiorstwa jako całości, zgodnie bowiem z treścią art. 316 oraz 318 p.u.n. ma ona priorytet przed sprzedażą zorganizowanej części przedsiębiorstwa. Jeśli potencjalny nabywca jest jeden, a sprzedaż nie dojdzie do skutku, to jeśli nie zgłosi się kolejny chętny, przedsiębiorstwo zostanie sprzedane w częściach. Nie jest to korzystne rozwiązanie, ponieważ w wyniku sprzedaży częściowej uzyskane kwoty są z reguły niższe niż w wypadku sprzedaży w całości, co oznacza mniejszy stopień zaspokojenia wierzycieli upadłego. Paradoksalnie, wydłużenie 
czasu na zawarcie umowy sprzedaży nie musi wydłużyć czasu trwania całego postępowania. Jeśli dodatkowe trzy miesiące spowodują, że oferent dokona zakupu, nie będzie konieczne ogłaszanie i przeprowadzanie nowych procedur sprzedaży, które znacznie wydłużają czas postępowania i z reguły prowadzą do uzyskania niższych kwot za zbywany majątek przy wyższych kosztach sprzedaży. Utrata szansy na sprzedaż przedsiębiorstwa jako całości jest niekorzystnym zjawiskiem również ze względu na konsekwencje związane z utrata miejsc pracy przez zwalnianych pracowników.

Kolejna zmiana, dotycząca art. 343 ust. 1 p.u.n., prowadzi do zwiększenia samodzielności syndyka oraz uproszczenia procedur i polega na umożliwieniu syndykowi zaspokajania wierzytelności pierwszej kategorii w miarę wpływu do masy środków bez konieczności uzyskania zgody sędziego komisarza. Oczekiwanie na postanowienie w tej sprawie mogło oddalać w czasie moment zapłaty przez syndyka kosztów postępowania upadłościowego w początkowej fazie jego trwania. Zapis mówiący o konieczności wydania takiego postanowienia przez sędziego komisarza w sytuacji, w której brak jego zgody na zaspokojenie wierzytelności pierwszej kategorii, mógł prowadzić do utraty przez syndyka możliwości prowadzenia postępowania, był nieuzasadniony merytorycznie.

Istotna zmiana z punktu widzenia zwiększania funduszy masy upadłości jest zmiana art. 345 ust. 1 p.u.n. Jej wprowadzenie umożliwiło zmniejszanie kwot uzyskanych z likwidacji przedmiotu obciążonego hipoteką oraz różnego rodzaju zastawami i przeznaczonych do podziału pomiędzy zabezpieczonych na nim wierzycieli, nie tylko o koszty sprzedaży tego przedmiotu, lecz także o kwotę innych kosztów postępowania. Kwota ta nie może być wyższa niż 10\% sumy, którą uzyskano ze sprzedaży, i większa, niż wynika to ze stosunku wartości tego przedmiotu do wartości całej masy upadłości. Przed wejściem w życie nowelizacji inne koszty postępowania, w tym także koszty związane ze sprzedawanym przedmiotem, ale niestanowiące kosztów jego sprzedaży (np. podatek od nieruchomości, opłata z tytułu użytkowania wieczystego, koszty ochrony i ubezpieczenia danego przedmiotu), w całości obciążały masę upadłości, a tym samym pozostałych, niezabezpieczonych wierzycieli dłużnika. Wprowadzenie zmiany może w istotny sposób przyczynić się do zwiększenia funduszy masy upadłości i - co jest z tym bezpośrednio związane - kwot odzyskiwanych wierzytelności przez wierzycieli niezabezpieczonych rzeczowo.

\section{NOWELIZACJA P.U.N. Z 22 PAŹDZIERNIKA 2010 R.}

Kolejna nowelizacja p.u.n. miała miejsce 22 października 2010 r. $^{9}$ Nowelizacja ta obejmuje tylko jeden artykuł - 28, który dotyczy zwrotu wniosku o ogłoszenie upadłości niespełniającego wymagań formalnych lub nieprawidłowo opłaconego. Do momentu wejścia w życie nowelizacji wniosek taki był wnioskodawcy zwracany bez wzywania do uzupełnienia lub opłacenia niezależnie od tego, czy został on złożony przez wnioskodawcę osobiście, czy przez

${ }^{9}$ Dz. U. 2010, Nr 230, poz. 1509. 
reprezentującego go adwokata lub radcę prawnego. Narzucony w ustawie termin 14 dni (liczony od momentu wystąpienia przesłanek) na złożenie wniosku o ogłoszenie upadłości wraz ze wszystkimi załącznikami jest terminem bardzo krótkim. Przedsiębiorcy działający osobiście, chcący dotrzymać tego terminu, a nieposiadajacy szczegółowej wiedzy na temat przepisów p.u.n. moga składać wnioski nieodpowiadające wymaganiom określonym w ustawie, co przed nowelizacją powodowało ich zwrot. Zwrócony wniosek o ogłoszenie upadłości nie wywołuje skutku prawnego. Zdaniem Trybunału Konstytucyjnego (wyrok z 10 listopada 2009 r. ${ }^{10}$ ) przepis taki był niezgodny z Konstytucja RP, a wynikające z niego konsekwencje dla wnioskodawców niereprezentowanych przez profesjonalnych pełnomocników były zbyt surowe.

Obecnie zgodnie z art. 28 ust. 1 p.u.n. zwrot wniosku bez wezwania do uzupełnienia ma miejsce tylko wtedy, gdy został on złożony przez wnioskodawcę reprezentowanego przez adwokata lub radcę prawnego. W ust. 2 tego artykułu określa się siedmiodniowy termin liczony od dnia doręczenia zarządzenia o zwrocie wniosku z przyczyn formalnych lub nieprawidłowego opłacenia, w którym uzupełnienie braków jest możliwe. Jeśli braki zostana uzupełnione i wniosek spełnia wszystkie wymagania przewidziane przepisami p.u.n., uznaje się, że wywołuje on skutek prawny od dnia jego pierwszego złożenia. Przepis ten nie ma jednak zastosowania w wypadku ponownego zwrotu wniosku z tej samej przyczyny lub jeśli wniosek został złożony przez wnioskodawcę działającego osobiście. Jeżeli wnioskodawca działa osobiście i jego wniosek będzie obarczony błędami formalnymi lub nieprawidłowo opłacony, sąd na podstawie art. 130 k.p.c. ${ }^{11} \mathrm{i}$ w związku $\mathrm{z}$ art. 35 p.u.n. (odesłanie do k.p.c. w sprawach nieuregulowanych w p.u.n.) wezwie wnioskodawcę do poprawienia, uzupełnienia lub opłacenia wniosku w terminie siedmiodniowym i zwróci wniosek dopiero po bezskutecznym upływie tego terminu.

Zmiana art. 28 p.u.n. w praktyce powoduje wzmocnienie ochrony wnioskodawcy działającego osobiście i zwiększa jego szanse na złożenie wniosku o ogłoszenie upadłości spełniającego wszystkie wymagania. W wypadku gdy wnioskodawcą jest dłużnik, jest to szczególnie ważne, gdyż wskazanie przez sąd konkretnych wymagań formalnych, które nie zostały spełnione, umożliwia ich szybkie uzupełnienie oraz złożenie kompletnego i poprawnego wniosku w terminie 7 dni od otrzymania wezwania, dzięki czemu wniosek wywoła skutek od daty pierwotnego wniesienia. Tym samym zachowany zostanie ustawowy termin na złożenie kompletnego wniosku o ogłoszenie upadłości, co może uchronić dłużnika od odpowiedzialności karnej z tytułu niedochowania terminu na złożenie tegoż wniosku.

Zmiana ta należy do grupy zmian mających na celu uproszczenie procedury składania wniosku o ogłoszenie upadłości, uczynienie prawa upadłościowego bardziej ,przyjaznym” stronom postępowania, a także dostosowanie go do przepisów ustawy zasadniczej.

10 Dz. U. 2009, Nr 191, poz. 1484.

${ }^{11}$ Ustawa z 17 listopada 1964 r. - Kodeks postępowania cywilnego, Dz. U. 1964, Nr 43, poz. 296 (dalej jako: k.p.c.). 


\section{NOWELIZACJA P.U.N. Z 9 CZERWCA 2011 R.}

Ostatnia znacząca, zdaniem autorów, nowelizacja przepisów p.u.n. miała miejsce 9 czerwca 2011 r. $^{12}$ Wprowadzone nią zmiany przepisów art. 26, 162, 187 polegają na obowiązkowym podwyższeniu wynagrodzenia syndyka masy upadłości, nadzorcy sądowego, zarządcy oraz kuratora o kwotę podatku od towarów i usług (VAT) zgodnie $\mathrm{z}$ obowiązującą $\mathrm{w}$ danej chwili stawką. Wynagrodzenie tych osób jest elementem kosztów postępowania, które z kolei zaliczane są do należności kategorii pierwszej. Do czasu nowelizacji ustawy p.u.n. wynagrodzenie przyznawane osobom, o których mowa w wyżej wymienionych artykułach, podlegało obowiązkowemu zmniejszeniu o kwotę podatku VAT zgodnie z przepisami ustawy z 11 marca 2004 r. o podatku o towarów i usług ${ }^{13}$. Nie powodowało to zwiększenia kosztów postępowania upadłościowego, obciążało natomiast przychody tych osób i wywoływało kontrowersje ze względu na występowanie luki prawnej. Syndyk, nadzorca sądowy i pozostałe osoby, których dotyczy nowelizacja, spełniają bowiem definicję płatnika podatku VAT, jednakże zasądzane im wynagrodzenia były wynagrodzeniami brutto i sąd nie mógł ich podwyższyć o kwotę tego podatku. W chwili obecnej kwota podatku VAT naliczona od wspomnianych wynagrodzeń podwyższa koszty postępowania i jednocześnie zmniejsza kwotę funduszy masy upadłości, nie obciążając jednocześnie przychodów wyżej wymienionych osób. Jednak gdy występuje nadwyżka podatku naliczonego nad należnym, kwota podatku VAT od wynagrodzeń podlega zwrotowi do masy upadłości i tym samym nie powoduje znaczącego wzrostu obciążenia funduszy masy w stosunku do sytuacji przed wprowadzeniem nowelizacji.

\section{PODSUMOWANIE}

Przeanalizowane w niniejszym artykule zmiany przepisów p.u.n. wprowadzone kilkoma nowelizacjami były konieczne i w większości wypadków korzystne z punktu widzenia m.in. efektywności ekonomicznej postępowań upadłościowych ${ }^{14}$. W praktyce nie zmieniły jednak anachronicznego, w ocenie autorów, charakteru prawa upadłościowego. Regulacje w nim zawarte nie nadążają bowiem za tempem zmian gospodarczych i aktualnymi uwarunkowaniami gospodarczymi. Polskie prawo upadłościowe i naprawcze bazuje na regulacjach zawartych w aktach prawnych z 1934 r., których źródeł należy szukać w rozwiązaniach pruskich i austriackich sprzed stu lat. Współczesne warunki gospodarcze sa jednak nieporównywalne do uwarunkowań gospodarczych z tamtego okresu. Ustawa regulująca postępowanie upadłościowe i postępowanie w przedmiocie ogłoszenia upadłości powinna zawierać przepisy

${ }^{12}$ Dz. U. 2011, Nr 142, poz. 828.

${ }^{13}$ Dz. U. 2004, Nr 53, poz. 535.

${ }^{14}$ Ze względu na brak odpowiednich danych liczbowych niemożliwa jest empiryczna weryfikacja potencjalnych skutków zmian przepisów przedstawionych w tym artykule. Przeprowadzenie takiej weryfikacji stanowiłoby cenne uzupełnienie badań prowadzonych przez autorów. 
uwzględniające tempo zachodzenia procesów gospodarczych, globalizacji, dużej dynamiki zmian własnościowych oraz zupełnie inny charakter powiązań finansowych i gospodarczych we współczesnym świecie. Nowe regulacje prawne powinny wymuszać szybką eliminację $\mathrm{z}$ obrotu gospodarczego podmiotów nieefektywnych ekonomicznie i niezdolnych do dalszego funkcjonowania na rynku, które przez niespłacanie zaciągniętych zobowiązań przyczyniają się do powstania niewypłacalności innych podmiotów, czyli do tzw. efektu domina upadłości. Szybsza upadłość podmiotu niewypłacalnego zwiększa szanse jego wierzycieli na odzyskanie środków finansowych i zainwestowanie ich w inny, efektywniejszy sposób. Zmiany przywołane w niniejszej publikacji jedynie w niewielkim stopniu wpływają na czas trwania postępowania upadłościowego, który w Polsce wynosi przeciętnie 3 lata $^{15}$, czyli jest dłuższy niż w większości państw europejskich (np. Węgry - 2 lata, Francja - 1,9 roku, Niemcy $-1,2 \mathrm{roku})^{16}$, i tym samym uniemożliwia szybkie oczyszczenie rynku $\mathrm{z}$ podmiotów niebędących w stanie dłużej na nim konkurować.

$\mathrm{Z}$ drugiej strony przepisy prawa powinny umożliwiać przedsiębiorcy, który doświadcza jedynie przejściowych trudności w terminowym regulowaniu swoich zobowiązań, skuteczną restrukturyzację i kontynuowanie działalności. Powinny więc zapewniać mu ochronę przed przedwczesnymi egzekucjami. Tymczasem w Polsce od wielu lat liczba postępowań upadłościowych z możliwością zawarcia układu stanowi mniej niż $20 \%$ wszystkich postępowań upadłościowych wszczynanych co roku przez wydziały upadłościowe sądów rejonowych. Dotychczas wprowadzone nowelizacje nie zmieniły tej sytuacji. Świadczy o tym różnica pomiędzy liczbą zawartych układów a liczbą ogłoszonych upadłości likwidacyjnych. Według statystyk Ministerstwa Sprawiedliwości w 2011 r. w Polsce ogłoszono 656 upadłości obejmujących likwidację majątku dłużnika i tylko 101 upadłości z możliwością zawarcia układu ${ }^{17}$. W 2010 r. liczba upadłości z możliwością zawarcia układu wyniosła 117, a z opcją likwidacyjną - 538 ${ }^{18}$. Przepisy o postępowaniu naprawczym są natomiast martwymi przepisami, ponieważ $\mathrm{w}$ zasadzie nie prowadzi się $\mathrm{w}$ Polsce tego rodzaju postępowań ${ }^{19}$. W $2010 \mathrm{r}$. w całej Polsce do sądów rejonowych wpłynęły tylko 22 wnioski o wszczęcie postępowania naprawczego, a w $2011 \mathrm{r}$. $-31^{20}$.

Prawo upadłościowe i naprawcze powinno również wprowadzać przepisy, które pomagaja chronić wierzycieli niewypłacalnego dłużnika i umożliwiaja przeprowadzenie postępowania upadłościowego w sposób zapewniający ich zaspokojenie w jak największym stopniu. Szacuje się, że wierzyciele w Polsce

${ }^{15}$ World Bank, op. cit., s. 189.

${ }^{16}$ World Bank, op. cit., s. 164, 165, 169.

${ }_{17}$ Ministerstwo Sprawiedliwości, Informacja statystyczna o ewidencji spraw $i$ orzecznictwie $w$ sadach powszechnych oraz o więziennictwie, cz. VII Sprawy gospodarcze $w 2011$ r., Warszawa 2012 r., dostępny na http://bip.ms.gov.pl/pl/dzialalnosc/statystyki/statystyki-2011/, s. 130 (dostęp: 1.11.2012).

${ }^{18}$ Coface Poland, Raport Coface nt. upadtości firm $w$ Polsce $w 2010$ r., http://www.coface.pl /CofacePortal/ShowBinary/BEA\%20Repository/PL/pl_PL/documents/Raport_Coface_upadlosci_caly_ 2010 (dostęp: 1.11.2012).

${ }^{19} \mathrm{~W}$ niniejszej publikacji pominięte zostały kwestie związane ze zmianami przepisów p.u.n. dotyczących postępowań naprawczych.

${ }^{20}$ Ministerstwo Sprawiedliwości, op. cit., s. 109. 
odzyskują swoje należności w około $50 \%{ }^{21}$ i kolejne nowelizacje p.u.n. nie wpływają znacząco na ten wynik. Brak badań w tym obszarze, ale ze względu na ściśle określoną w p.u.n. kolejność zaspokajania roszczeń (najpierw Skarb Państwa, ZUS, pracownicy, na końcu wierzyciele niezabezpieczeni) można domniemywać, że wierzyciele, których roszczenia zostały zaliczone do najdalszych kategorii, nie są zaspokajani w ogóle.

Regulacje prawne nie moga także legitymizować sytuacji, w których niewypłacalni dłużnicy świadomie nie składają wniosków o ogłoszenie upadłości przez wiele miesięcy od wystąpienia ku temu przesłanek, gdyż w takich sytuacjach szansa na pokrycie zobowiązań dłużnika ze środków uzyskanych ze sprzedaży jego majątku jest niewielka z racji utraty wartości tego majątku, lub w ogóle niemożliwa, dlatego że majątek dłużnika nie wystarcza nawet na pokrycie kosztów postępowania. W 2011 r. w Polsce sądy oddaliły $1097^{22}$ wniosków o ogłoszenie upadłości. Wnioski te oddalane są najczęściej z jednego z dwóch powodów: braku środków w masie upadłości na pokrycie kosztów postępowania lub gdy opóźnienie w wykonaniu zobowiązań nie przekracza trzech miesięcy, a suma niewykonanych zobowiązań nie przekracza $10 \%$ wartości bilansowej przedsiębiorstwa (art. 12 p.u.n.) ${ }^{23}$. Brak dokładnych danych o tym, jaka część wniosków oddalana jest z pierwszego, a jaka z drugiego powodu. Przypuszczalnie większość postanowień o oddaleniu wniosku wydaje się w Polsce z powodu braku środków na pokrycie kosztów postępowania. W wyniku niezgodnych $\mathrm{z}$ prawem działań dłużników prawo własności nie zawsze jest więc wykonywane, a zwiększone w związku z tym ryzyko zawierania transakcji gospodarczych powoduje wzrost kosztów, które się z nimi wiążą. Jeśli wierzyciele mają pewność, że w wypadku upadłości dłużnika odzyskaja swoje należności w zadowalającym stopniu, koszt pożyczania pieniędzy jest niższy, ponieważ ryzyko niespłacenia kredytu/pożyczki również jest odpowiednio niższe. Tym samym więcej podmiotów korzysta $\mathrm{z}$ finansowania zewnętrznego. Ponieważ finansowanie zewnętrzne jest podstawowym rodzajem finansowania inwestycji, które z kolei są istotnym czynnikiem wzrostu gospodarczego każdego kraju, łatwość uzyskania takiego finansowania przekłada się na wyższy wzrost gospodarczy. $Z$ tego powodu istotne i konieczne jest wprowadzenie takich zmian w Prawie upadłościowym i naprawczym, które doprowadzą do poprawy efektywności i przejrzystości całego systemu upadłościowego w Polsce.

mgr Dorota Mirowska

Uniwersytet Warszawski

dmirowska@wne.uw.edu.pl

mgr Waldemar Mirowski

${ }^{21}$ World Bank, op. cit., s. 189.

${ }^{22}$ Ministerstwo Sprawiedliwości, op. cit., s. 130.

23 S. Gurgul, op. cit., s. 59. 


\section{CONSEQUENCES OF THE AMENDMENTS TO POLISH BANKRUPTCY} AND REORGANISATION LAW INTRODUCED BETWEEN 2009 AND 2011

\section{Summary}

The Bankruptcy and Reorganisation Law governs the launching of a collective creditor action aimed to recover receivables from insolvent debtors. The Law was enacted in Poland on 28 February 2003 and entered into force on 1 October 2003. Since then it has been amended a number of times, and the main amendments, in the authors' opinion, took place on 6 March 2009, 22 October 2010 and 9 June 2011. Despite these frequent amendments, voices in relevant literature call for further revisions of the law. In this paper, economic and legal consequences of the introduced amendments on the debtor, the creditors and other stakeholders of bankruptcy proceeding are analysed, followed by an attempt to determine whether these amendments are indeed relevant and most suitable. 
Copyright of Journal of Law, Economics and Sociology is the property of Faculty of Law and Administration of Adam Mickiewicz University in Poznan and its content may not be copied or emailed to multiple sites or posted to a listserv without the copyright holder's express written permission. However, users may print, download, or email articles for individual use.

Właścicielem praw autorskich do „Ruchu Prawniczego, Ekonomicznego i Socjologicznego” jest Wydział Prawa i Administracji Uniwersytetu im. Adama Mickiewicza w Poznaniu. Zawartość czasopisma nie może być kopiowana, przesyłana do innych stron internetowych bądź zamieszczana na blogach bez pisemnej zgody wydawcy. Niemniej artykuły można drukować, kopiować lub przesyłać w formie elektronicznej na własny użytek. 